\title{
An open ocean record of the Toarcian oceanic anoxic event
}

\author{
D. R. Gröcke ${ }^{1}$, R. S. Hori ${ }^{2}$, J. Trabucho-Alexandre ${ }^{1}$, D. B. Kemp ${ }^{3}$, and L. Schwark ${ }^{4}$ \\ ${ }^{1}$ Department of Earth Sciences, Durham University, Science Laboratories, South Road, Durham, DH1 3LE, UK \\ ${ }^{2}$ Department of Earth Sciences, Faculty of Science, Ehime University, Matsuyama 790-8577, Japan \\ ${ }^{3}$ Department of Earth Sciences, University of Cambridge, Downing Street, Cambridge, CB2 3EQ, UK \\ ${ }^{4}$ Christian-Albrechts-University-Kiel, Institute for Geosciences, Ludewig-Meyn-Str. 10, 24118 Kiel, Germany
}

Received: 4 April 2011 - Published in Solid Earth Discuss.: 7 April 2011

Revised: 6 October 2011 - Accepted: 12 October 2011 - Published: 11 November 2011

\begin{abstract}
Oceanic anoxic events were time intervals in the Mesozoic characterized by widespread distribution of marine organic matter-rich sediments (black shales) and significant perturbations in the global carbon cycle. These perturbations are globally recorded in sediments as carbon isotope excursions irrespective of lithology and depositional environment. During the early Toarcian, black shales were deposited on the epi- and pericontinental shelves of Pangaea, and these sedimentary rocks are associated with a pronounced (ca. 7\%o) negative (organic) carbon isotope excursion (CIE) which is thought to be the result of a major perturbation in the global carbon cycle. For this reason, the lower Toarcian is thought to represent an oceanic anoxic event (the T-OAE). If the TOAE was indeed a global event, an isotopic expression of this event should be found beyond the epi- and pericontinental Pangaean localities. To address this issue, the carbon isotope composition of organic matter $\left(\delta^{13} \mathrm{C}_{\mathrm{org}}\right)$ of lower Toarcian organic matter-rich cherts from Japan, deposited in the open Panthalassa Ocean, was analysed. The results show the presence of a major $\left(>6 \%\right.$ ) negative excursion in $\delta^{13} \mathrm{C}_{\mathrm{org}}$ that, based on radiolarian biostratigraphy, is a correlative of the lower Toarcian negative CIE known from Pangaean epiand pericontinental strata. A smaller negative excursion in $\delta^{13} \mathrm{C}_{\text {org }}$ (ca. 2\%o) is recognized lower in the studied succession. This excursion may, within the current biostratigraphic resolution, represent the excursion recorded in European epicontinental successions close to the Pliensbachian/Toarcian boundary. These results from the open ocean realm suggest, in conjunction with other previously published datasets, that these Early Jurassic carbon cycle perturbations affected the active global reservoirs of the exchangeable carbon cycle (deep marine, shallow marine, atmospheric).
\end{abstract}

Correspondence to: D. R. Gröcke

(d.r.grocke@durham.ac.uk)

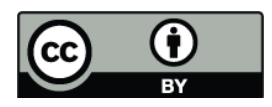

\section{Introduction}

Over the past decade, there has been an increased effort to unravel the cause(s) and consequences of the early Toarcian oceanic anoxic event (T-OAE). The presence of a pronounced, transient negative carbon isotope $\left(\delta^{13} \mathrm{C}\right)$ excursion is of diagnostic significance. The excursion has been recognized in marine inorganic and organic matter (Jenkyns and Clayton, 1986; Schouten et al., 2000; Kemp et al., 2005; Suan et al., 2008), and terrestrial plant material (Hesselbo et al., 2000, 2007). Associated with the T-OAE is concomitant evidence for: a threefold increase in atmospheric $\mathrm{CO}_{2}$ levels (McElwain et al., 2005), a rise in seawater palaeotemperatures (Rosales et al., 2004; van de Schootbrugge et al., 2005), an increase in silicate weathering rates (Cohen et al., 2004; Waltham and Gröcke, 2006) and a biotic crisis affecting marine invertebrates and biocalcifying microorganisms (Little and Benton, 1995; Mattioli et al., 2004; Tremolada et al., 2005).

The lithological expression of the T-OAE may be locally very different. The development of anoxic, organic matterrich facies was not ubiquitous in the European Neotethyan realm and, where developed, the petrology and organic matter richness of the sediments is variable. For instance, certain limestones in the Harpoceras falciferum ammonite Zone of northern Europe (Hallam, 1967) and of the Tethys (Jenkyns, 1985) are pink/red. These differences illustrate the importance of local environmental conditions, which are ultimately more important in determining the lithology of deposits formed during an OAE (Trabucho-Alexandre et al., 2011). Available biostratigraphic data indicate that the development and demise of organic matter-rich facies in Tethyan and Boreal provinces of Europe are diachronous (Wignall et al., 2005 and references therein) as is the case for the Cenomanian/Turonian boundary OAE 2 (Tsikos et al., 2004).

(d.r.grocke@durham.ac.uk)

Published by Copernicus Publications on behalf of the European Geosciences Union. 
Hesselbo et al. (2000) suggested that the cause of the negative carbon isotope excursion concurrent with the T-OAE was the dissociation, release and consequent oxidation of methane derived from continental slope hydrates: subsequently modelled by Beerling et al. (2002). More recently, a high-resolution $\delta^{13} \mathrm{C}_{\text {org }}$ record across the T-OAE obtained from mudstones exposed in northeast England was generated by Kemp et al. (2005). These data suggest that the negative $\delta^{13} \mathrm{C}$ excursion was not a single event but three rapid events, the timing of which was interpreted as having been paced by astronomically forced climate/ocean cycles. An alternative hypothesis recently put forward for the cause of the T-OAE is that ${ }^{12} \mathrm{C}$-enriched thermogenic methane was released into the ocean-atmosphere system due to an igneous intrusion into coaly organic matter-rich facies in the Karoo Basin, South Africa (McElwain et al., 2005; Svensen et al., 2007). This mechanism has been questioned by Gröcke et al. (2009), who showed that both the physical nature of the contacts between intrusions and organic matter-rich facies, and the geochemical pattern within these facies suggest little or no thermogenic methane generation in the Karoo Basin.

Localities where the negative $\delta^{13} \mathrm{C}$ excursion that defines the T-OAE has been found are chiefly restricted to epicontinental sections in Europe. Moreover, the negative $\delta^{13} \mathrm{C}$ excursion is absent in data generated using belemnite calcite from NW Europe (van de Schootbrugge et al., 2005; Wignall et al., 2006; McArthur et al., 2008). The excursion is, however, present in bulk calcite; additionally, Suan et al. (2008) recently reproduced the negative $\delta^{13} \mathrm{C}$ excursion in brachiopod calcite across the T-OAE from a section in Peniche, Portugal. Nevertheless, the absence of a negative excursion in belemnite calcite prompted speculation that the isotope perturbation affected only the shallow marine environment (i.e. $<200 \mathrm{~m}$ water depth) and that it was driven by local phenomena (van de Schootbrugge et al., 2005). Recently, however, Al-Suwaidi et al. (2010) documented evidence for the lower Toarcian negative $\delta^{13} \mathrm{C}$ excursion from strata in the Neuquén Basin, Argentina. This record revealed the onset of the excursion, although the main excursion interval was not documented owing to the presence of an unconformity that truncates the succession. Caruthers et al. (2011) have also documented the lower Toarcian negative $\delta^{13} \mathrm{C}$ excursion from strata in the Queen Charlotte Islands, Canada, where the record is more complete. Although both records represent deposition in relatively shallow marine environments, they demonstrate that the carbon isotope excursion (CIE) associated with the T-OAE is not only present in the Neotethyan realm.

In this study, the specific issue of the global extent of the lower Toarcian negative $\delta^{13} \mathrm{C}$ excursion, as well as the physical expression of the T-OAE in the open ocean, are addressed by analysing a chert succession from Katsuyama, Japan (Fig. 1), which was located in the middle of the palaeoPacific (Panthalassic) Ocean during the Early Jurassic.

\section{Geological setting}

The studied samples were obtained from Katsuyama in the Inuyama area, Mino Terrane, which is one of the Mesozoic accretionary complexes presently exposed in Japan, extending to the north of Tokyo (Ashio Terrane) and lithostratigraphically corresponding to the Chichibu Terrane (Fig. 2). These Mesozoic complexes consist of seamount-related sequences of volcanic rocks, limestones and pelagic sediments (bedded chert and siliceous mudstone) associated with trench-fill sediments. The former sediments were deposited on the seafloor of the Izanagi Plate from Carboniferous to Early Cretaceous and were subsequently accreted to the margin of Far East Asia during the Jurassic to Early Cretaceous (Matsuda and Isozaki, 1991).

The sedimentary succession in the Inuyama area mainly consists of bedded cherts spanning the Early TriassicEarly/Middle Jurassic, which have been well constrained using conodont and radiolarian biostratigraphy (e.g., Yao et al., 1982; Hori, 1990, 1993; Matsuoka, 2004). The sedimentary complex of this area was formed by accretionary processes at shallow depths (Kimura and Hori, 1993), and underwent low-grade metamorphism (diagenetic zone of illite crystallinity index; Otsuka and Watanabe, 1992). Therefore, it is considered that the cherts retain a primary record of the Late Triassic and Early Jurassic depositional environments. The studied pelagic sediments in the Inuyama area are typical distal, open ocean sediments characterized by sedimentation rates of $1 \mathrm{~m}$ to $7 \mathrm{~m} \mathrm{Myr}^{-1}$ and long sequences (>50 Myr) (Hori et al., 1993; Wignall et al., 2010). Although such sediments are generally considered analogous to present-day deep-sea radiolarian ooze ( $>3 \mathrm{~km}$ water depth), similar Meso-Cenozoic sequences were interpreted as having been deposited at much shallower water depths (e.g. Iijima et al., 1979; Wilson et al., 1998; Jenkyns and Wilson, 1999; Robinson et al., 2004).

Palaeomagnetic studies reveal that the studied cherts of the Inuyama area were deposited at low Southern Hemisphere latitudes during the Middle Triassic and migrated to the Northern Hemisphere during the Late Triassic-Early Jurassic (Shibuya and Samejima, 1986; Ando et al., 2001), crossing the equatorial regions of the palaeo-Pacific (Fujii et al., 1993; Ando et al., 2001).

\subsection{Biostratigraphy of the Katsuyama section}

The biostratigraphy of the sequence at Katsuyama, located in the northern part of the Inuyama area, has been well studied (Hori, 1990, 1992, 1997; Takeuchi, 2001; Matsuoka, 2004). The studied sequence consists of a continuous succession of bedded cherts (Fig. 3a-d) which, based on radiolarian biostratigraphy (Matsuoka et al., 1995), spans the upper Lower Triassic (Spathian) to lower Middle Jurassic (Aalenian). Over the Lower Jurassic part of the succession, five radiolarian (sub)zones are recognized: the 


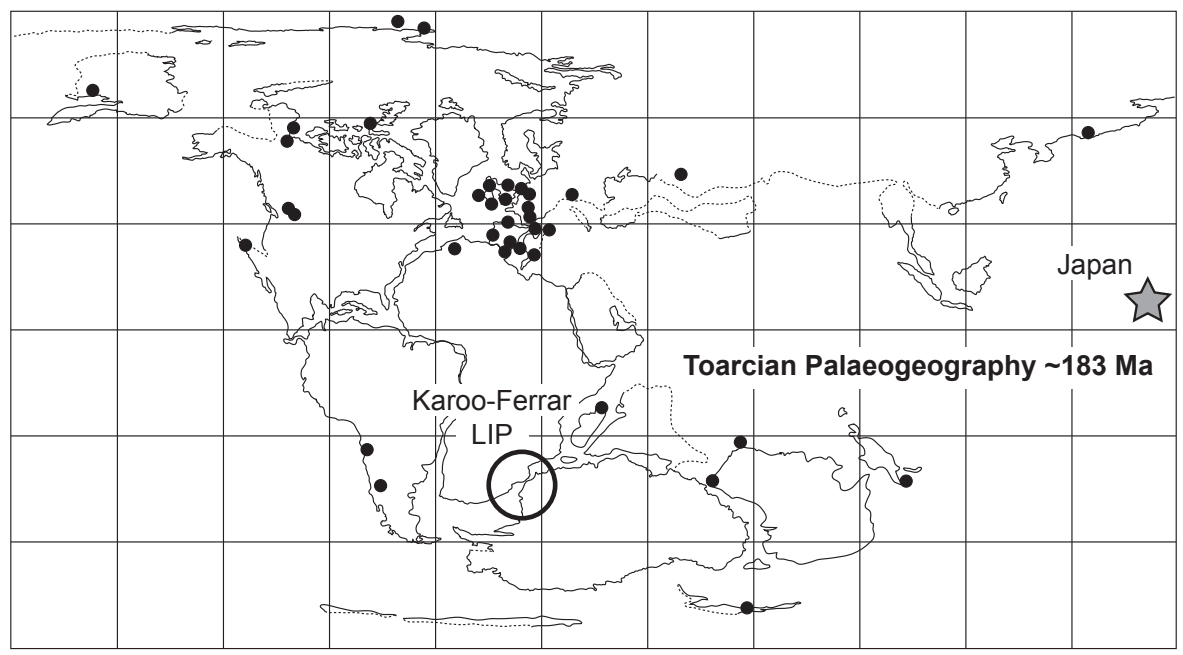

Fig. 1. Palaeogeographic map of the Early Jurassic showing the distribution of organic matter-rich facies (filled circles) dated as early Toarcian (modified from Jenkyns et al., 2002). The star indicates the approximate palaeogeographic location of Japan during the deposition of the Toarcian succession. The large circle represents the location of the Karoo-Ferrar large igneous province.

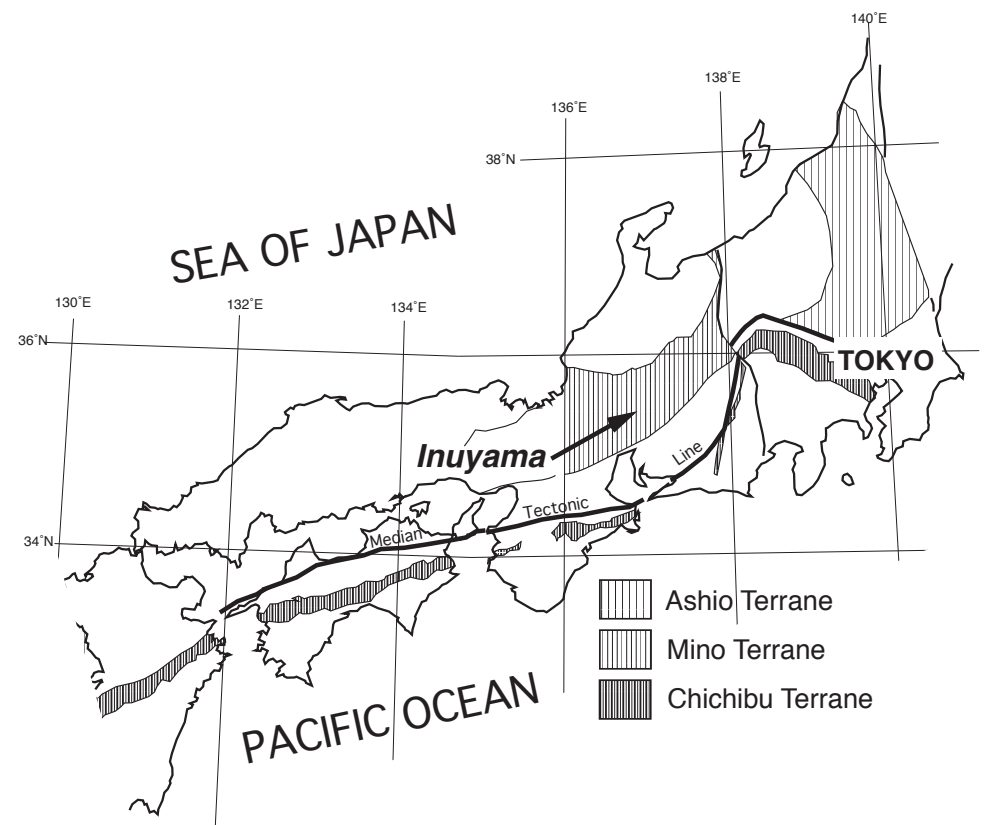

Fig. 2. Geographic map of Japan showing the three accretionary complexes presently exposed - Ashio Terrane, Mino Terrane and Chichibu Terrane - and the position of the Inuyama area.

Parahsuum simplum Subzones I to IV, and the Mesosaturnalis hexagonus (=Hexasaturnalis hexagonus) Zone (in ascending order) (Hori, 1990, 1997). The samples for the present isotope study were obtained from the interval spanning the upper part of the $P$. simplum IV (Ps IV) Subzone to the lower part of the H. hexagonus (Hh) Zone, which comprises a ca. $340 \mathrm{~cm}$-thick sequence of bedded chert. On the basis of a $1 \mathrm{~m} \mathrm{Myr}^{-1}$ sedimentation rate for the Lower Jurassic cherts of the Inuyama area (Hori et al., 1993), the studied interval is calculated to have lasted a maximum of ca. 3.5 Myr (Fig. 4). This equates to the radiolarian zones in Carter et al. (2010) of Eucyrtidiellum nagaiae - Praeparvicingula tlellensis to Elodium pessagnoi - H. hexagonus (Fig. 4). The radiolarian zones were constrained by ammonite data from Queen Charlotte Islands, Canada and other areas from North America (Carter et al., 2010). According to their radiolarian zonation, and considering the presence of $H$ suum exiguum, the base of E. pessagnoi $-H$. hexagonus 

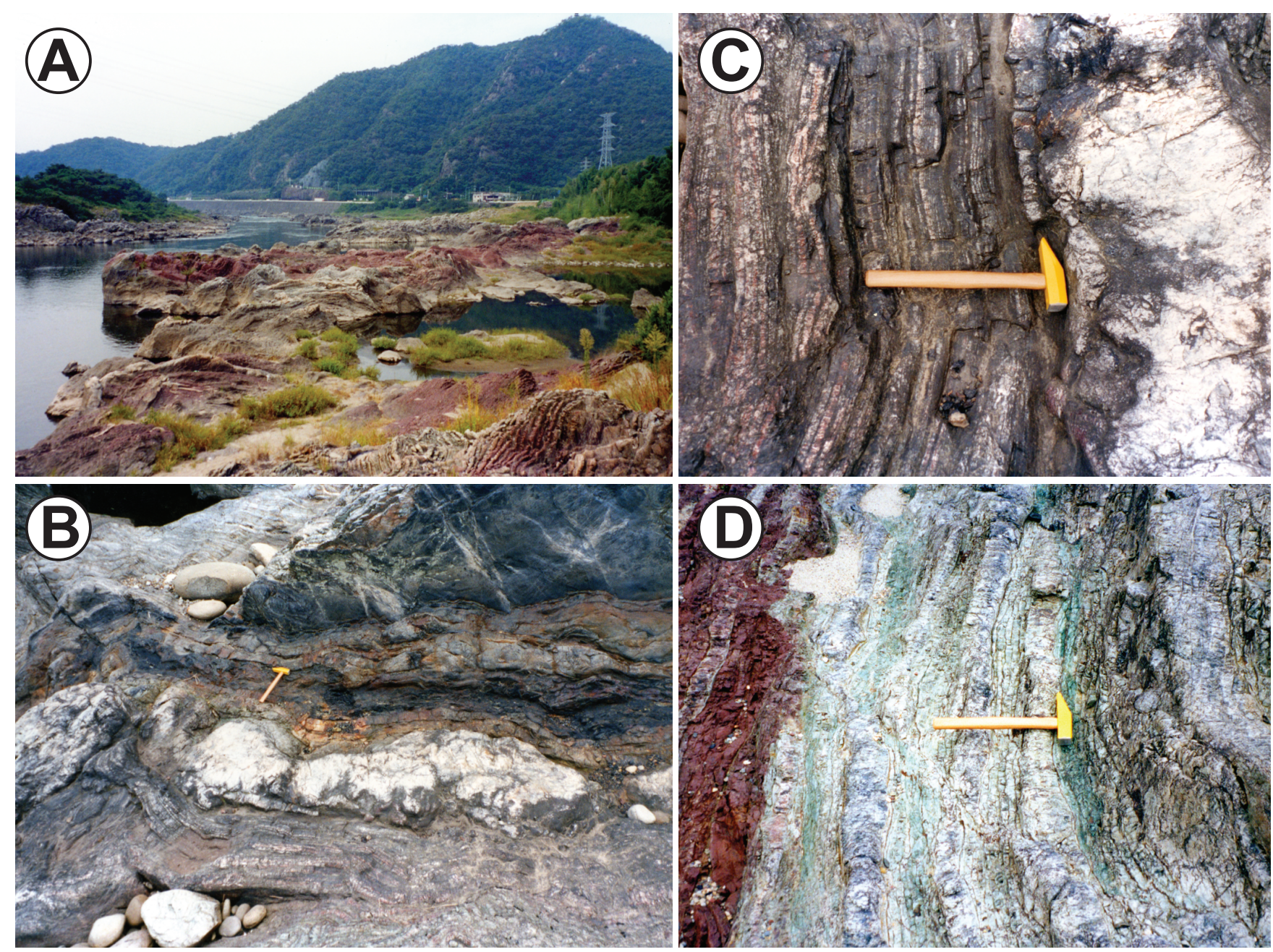

Fig. 3. (A) Katsuyama section on the Kiso River, Inuyama, Japan. (B) View of the Pliensbachian-Toarcian interval showing the organic matter-rich cherts beneath the continuous white bedded-chert horizon. (C) Close-up from photograph B of the T-OAE organic matter-rich cherts above the white bedded-chert horizon. (D) Upper interval of the Toarcian section showing the change between red-grey and green and red-green bedded cherts: the Toarcian Radiolarian Event occurs between the contact of the green to red-green bedded cherts. Note: hammer in photographs is approximately $30 \mathrm{~cm}$ in length and the head of the hammer is in the direction of the base of the stratigraphic section (see Fig. 4 for stratigraphic positions).

zone (ca. $100 \mathrm{~cm}$ level in Fig. 4) is equivalent to the $H$. falciferum/Hildoceras bifrons ammonite Zone boundary of NW Europe. However, this tie-point in the biostratigraphic framework is based on the presence of a single species (H. exiguum). The other two species at ca. $100 \mathrm{~cm}$ level are Parahsuum longiconicum and P. simplum, which have little stratigraphic significance because they have long age ranges. Therefore, we provide two possible biostratigraphic schemes: Carter et al. (2010) and Carter et al. (2010 sensu Hori, 2011, unpublished) (Fig. 4). Hereafter, we use the biostratigraphic scheme of Carter et al. (2010) as shown in Fig. 3.

A distinct change in lithology is observed within the upper part of the Lower Jurassic succession (Fig. 3b, c; $240-250 \mathrm{~cm}$ ). This interval is further characterized by a remarkable faunal change at the E. pessagnoi-H. hexagonus Zone, termed the Toarcian Radiolarian Event (Hori, 1997). Prior to the Toarcian Radiolarian Event, organic matter-rich black chert beds occur in two distinct intervals (ca. $40-90 \mathrm{~cm}$ and ca. 180-210 cm: Napora relica - Eucyrtidiellum disparile Zone, Fig. 4) that are separated by a massive white chert bed and black-white chert beds containing rhodochrosite minerals (Fig. 3b, c). White chert may be the product of silicification of volcaniclastic rocks. The lithologies of this interval differ from the more predominant red cherts found upsection. Wignall et al. (2010) analysed samples from Katsuyama and suggested anoxic depositional conditions based on the study of pyrite framboids. The correlation with their published log of the succession with the one presented here is 

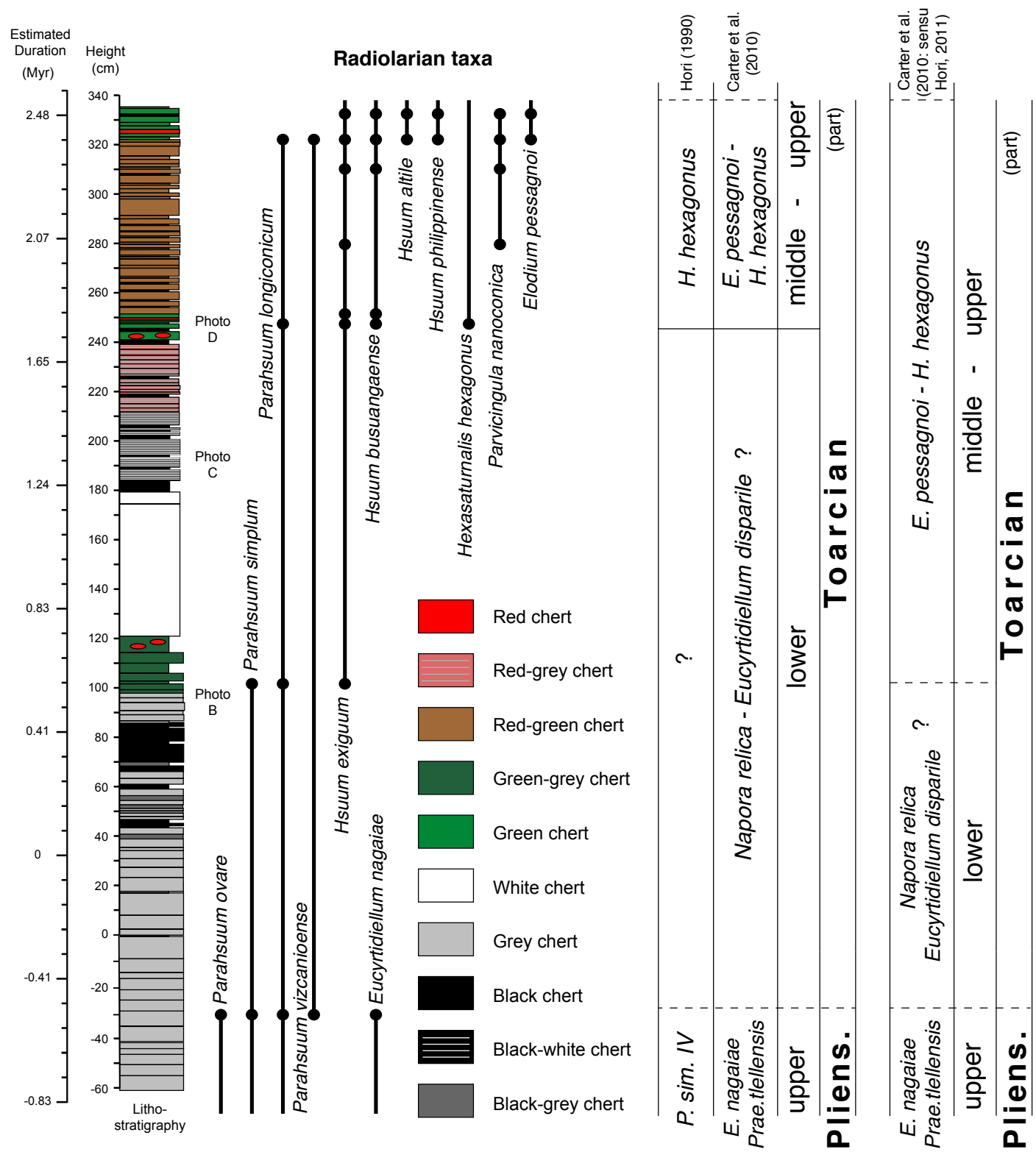

Fig. 4. Detailed lithostratigraphic log and biostratigraphy of the Katsuyama section, Inuyama, Japan. The stratigraphic positions of the photographs depicted in Fig. 3 are indicated beside the section. Radiolarian biostratigraphy is from Hori (1997) and modified according to Carter et al. (2010). There are two possible biostratigraphic zonation schemes used here: Carter et al. (2010) and Carter et al. (2010 sensu Hori, 2011, unpublished). See text for discussion. The major difference between these two zonations is based on the presence of only one species (Hsuum exiguum) to define to the middle Toarcian. On the basis of a $1 \mathrm{~m} \mathrm{Myr}^{-1}$ sedimentation rate for the Lower Jurassic chert succession at Inuyama, the studied interval is calculated to be ca. 3.5 Myr in duration (see Hori et al., 1993).

ambiguous. The log presented by Wignall et al. (2010; their figure 7) shows a studied interval spanning $90 \mathrm{~cm}$, whereas $340 \mathrm{~cm}$ were studied here (Fig. 4). Wignall et al. (2010) do not present biostratigraphic data in their study; however, it appears that their studied interval roughly corresponds to the interval between 20-120 cm (Fig. 4; Wignall, 2011; personal communication).

\section{Analytical methodology}

Bulk sediment samples were decalcified using $3 \mathrm{M} \mathrm{HCl}$ in $50 \mathrm{ml}$ centrifuge tubes for $16 \mathrm{~h}$. Stable isotope measurements were performed at Durham University using a Costech elemental analyser (ESC4010) coupled to a ThermoFinnigan Delta V Advantage isotope ratio mass spectrometer. Carbon isotope ratios are corrected for ${ }^{17} \mathrm{O}$ contribution and 


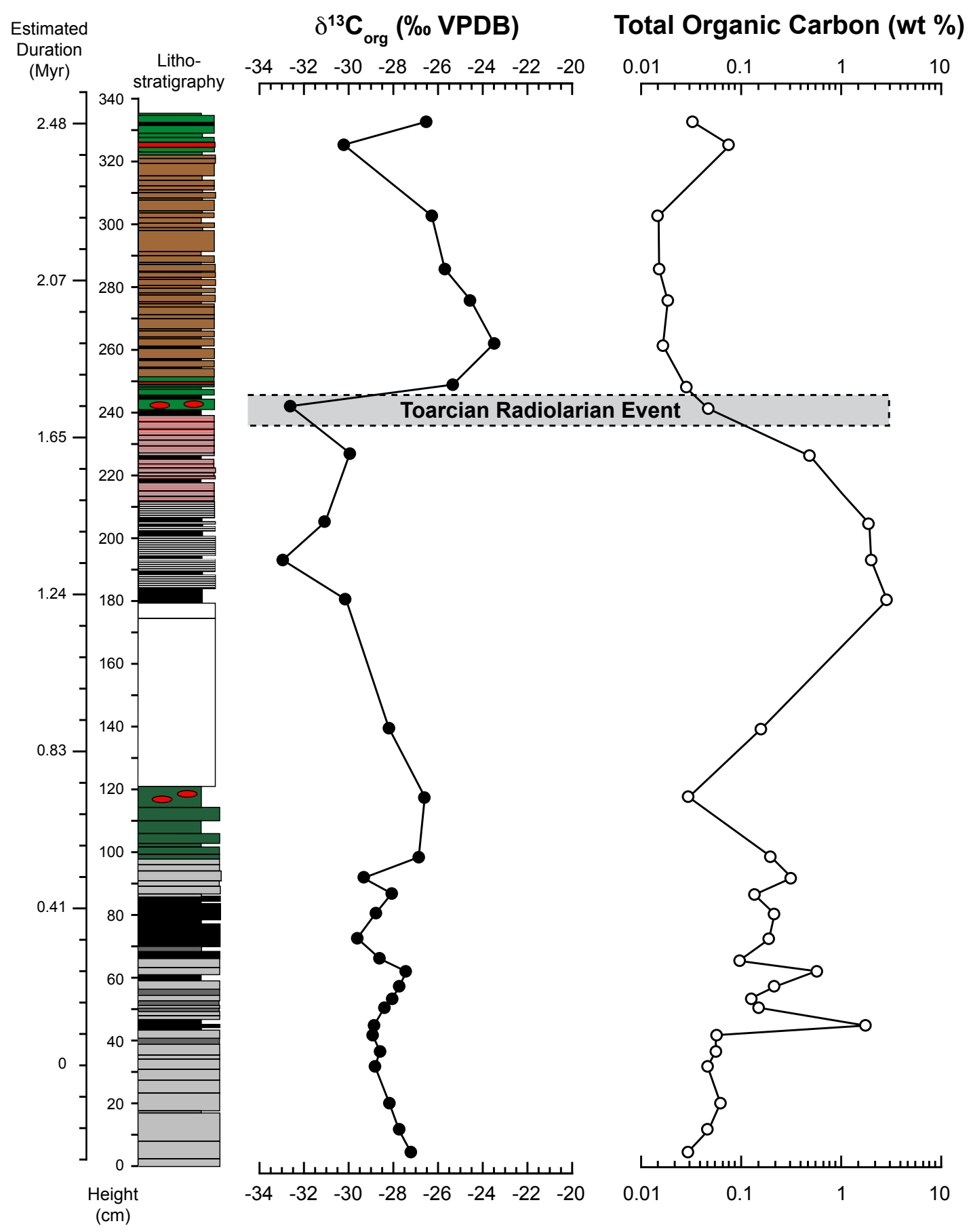

Fig. 5. Organic carbon isotope record $\left(\delta^{13} \mathrm{C}_{\text {org }}\right)$ of the Katsuyama section, Inuyama, Japan. Total organic carbon (TOC) as weight percent (wt \%) was determined during stable isotope measurements. Note that the scale for TOC is logarithmic. The chert sample at ca. $212 \mathrm{~cm} \mathrm{has}$ a $\delta^{13} \mathrm{C}_{\text {org }}$ value of $-57 \%$ o: whilst this value has been replicated, it is possible that this particular sample is somehow contaminated. The Toarcian Radiolarian Event is also depicted at ca. 240 cm. See Fig. 3 for lithostratigraphic and biostratigraphic details.

reported in standard delta $(\delta)$ notation in per mil (\%o) relative to VPDB. Data accuracy is monitored through routine analyses of international and in-house standards: the latter are stringently calibrated against the international standards. Analytical uncertainty for $\delta^{13} \mathrm{C}_{\text {org }}$ measurements was typically better than $\pm 0.1 \%$ o for standards and $<0.2 \%$ o on replicate sample analysis. Total organic carbon (TOC) data was obtained as part of this method. Because of the low 
Table 1. Isotope and total organic carbon (TOC) results from the Katsuyama section, Inuyama, Japan.

\begin{tabular}{cccc}
\hline Sample ID & Height $(\mathrm{cm})$ & $\delta^{13} \mathrm{C}_{\text {org }}$ & TOC $(\mathrm{wt} \%)$ \\
\hline INTO-32 & 333 & -26.58 & 0.03 \\
INTO-31 & 325 & -30.22 & 0.07 \\
INTO-30 & 304 & -26.36 & 0.01 \\
INTO-29 & 286 & -25.77 & 0.01 \\
INTO-28 & 277 & -24.60 & 0.02 \\
INTO-27 & 262 & -23.55 & 0.02 \\
INTO-26 & 249 & -25.39 & 0.03 \\
INTO-25 & 242 & -32.60 & 0.05 \\
INTO-24 & 227 & -29.95 & 0.48 \\
INTO-23 & 212 & -57.93 & 1.41 \\
INTO-22 & 205 & -31.07 & 1.93 \\
INTO-21 & 193 & -32.91 & 1.93 \\
INTO-20 & 180 & -30.17 & 2.75 \\
INTO-19 & 140 & -28.24 & 0.16 \\
INTO-18 & 118 & -26.64 & 0.03 \\
INTO-17 & 99 & -26.92 & 0.20 \\
INTO-16 & 92 & -29.37 & 0.31 \\
INTO-15 & 87 & -28.09 & 0.14 \\
INTO-14 & 80 & -28.83 & 0.22 \\
INTO-13 & 73 & -29.65 & 0.19 \\
INTO-12 & 66 & -28.62 & 0.09 \\
INTO-11 & 62 & -27.43 & 0.57 \\
INTO-10 & 58 & -27.79 & 0.21 \\
INTO-9 & 53 & -28.14 & 0.13 \\
INTO-8 & 50 & -28.36 & 0.16 \\
INTO-7 & 45 & -28.87 & 1.77 \\
INTO-6 & 42 & -29.00 & 0.06 \\
INTO-5 & 36 & -28.63 & 0.06 \\
INTO-4 & 32 & -28.86 & 0.05 \\
INTO-3 & 20 & -28.18 & 0.07 \\
INTO-2 & 12 & -27.81 & 0.05 \\
INTO-1 & 5 & -27.29 & 0.03 \\
\hline
\end{tabular}

TOC contents of the studied chert samples, the tin capsules used contained up to 100-120 mg of powdered chert, and the Costech was set to Macro- $\mathrm{O}_{2}$ in order to deliver more oxygen and make certain that complete combustion of the silicate occurred to liberate all organic carbon. The isotope analyses were done in "no dilution mode" so that the maximum amount of $\mathrm{CO}_{2}$ gas is delivered to the source of the mass spectrometer and all results produced more than $1000 \mathrm{mV}$.

\section{Results and discussion}

\subsection{Correlation of the Pliensbachian-lower Toarcian $\delta^{13}$ C curve}

At Katsuyama, the $\delta^{13} \mathrm{C}_{\text {org }}$ record reveals two negative shifts - the first between ca. $60 \mathrm{~cm}$ to ca. $100 \mathrm{~cm}$ and the second between ca. $180 \mathrm{~cm}$ to ca. $240 \mathrm{~cm}$ (Fig. 5; Table 1).
The excursion between ca. $60 \mathrm{~cm}$ and ca. $100 \mathrm{~cm}$ involves a change in $\delta^{13} \mathrm{C}_{\text {org }}$ of ca. $2 \%$, whereas the excursion from ca. $180 \mathrm{~cm}$ to ca. $240 \mathrm{~cm}$ represents a more pronounced perturbation with values shifting from ca. $-30 \%$ o to $-33 \%$. Within this negative $\delta^{13} \mathrm{C}_{\text {org }}$ excursion one sample (at ca. $212 \mathrm{~cm}$ ) records a $\delta^{13} \mathrm{C}_{\text {org }}$ value of $-57 \%$. Whilst this value has been replicated, it is possible that this particular sample is somehow contaminated. For this reason, it is not included in Fig. 5 or discussed hereafter. At ca. $250 \mathrm{~cm}$, coinciding with the Toarcian Radiolarian Event, $\delta^{13} \mathrm{C}_{\text {org }}$ values markedly increase from ca. $-33 \%$ to ca. $-25 \%$. This increase to less negative values, a positive excursion, is also coincident with a return to lower TOC values (Fig. 5; Table 1).

Coupling of the age constraints of the Katsuyama succession (Fig. 4) to $\delta^{13} \mathrm{C}_{\text {org }}$ variations shows that the negative CIE occurring between ca. $180 \mathrm{~cm}$ and ca. $250 \mathrm{~cm}$ height in the succession (Fig. 5) is the lower Toarcian negative CIE. The Katsuyama succession can be correlated with lower Toarcian successions in Europe using radiolarian biostratigraphy in combination with the carbon isotope record from various sites (Fig. 6).

The data also support the inference that the ca. $2 \%$ negative excursion between ca. $60 \mathrm{~cm}$ and ca. $100 \mathrm{~cm}$ height (Fig. 5) represents the excursion found in European sections at the Pliensbachian/Toarcian boundary. Evidence for a Pliensbachian/Toarcian negative CIE from Europe has been documented from sections in Yorkshire (Littler et al., 2009) and Peniche (Hesselbo et al., 2007; Suan et al., 2008) and is also apparent in the Mochras Farm record of Wales (Jenkyns et al., 2001) (Fig. 6). In the Argentinean $\delta^{13} \mathrm{C}_{\text {org }}$ record presented by Al-Suwaidi et al. (2010), however, clear evidence for a negative shift at the Pliensbachian/Toarcian boundary is absent. As such, the data from the Katsuyama succession potentially represent the first evidence for the Pliensbachian/Toarcian $\delta^{13} \mathrm{C}_{\text {org }}$ excursion outside Europe and in an open ocean setting. In the Katsuyama succession, the rise in TOC occurs prior to the proposed Pliensbachian/Toarcian CIE, and TOC continues to rise (with the exception of one sample at ca. $118 \mathrm{~cm}$ ) until the second sequence of organic matter-rich cherts and negative $\delta^{13} \mathrm{C}_{\text {org }}$ values (ca. $180 \mathrm{~cm}$; Fig. 5). However, while the $\delta^{13} \mathrm{C}_{\text {org }}$ values remain negative during the T-OAE TOC decreases to the Toarcian Radiolarian Event: thus, it differs from the T-OAE record in NW Europe, which indicates a TOC rise during the most negative part of the T-OAE CIE (cf. Hesselbo et al., 2000; Jenkyns et al., 2002; Kemp et al., 2005). In southern Europe, however, the development of organic matter-rich facies during the early Toarcian, at localities where organic matter enrichment occurred at all (e.g. Hallam, 1967; Jenkyns, 1985), also occurred prior to the CIE (Wignall et al., 2005). These differences in the timing of organic matter enrichment and carbon isotope excursions illustrate the importance of local sedimentary processes, which are largely independent from global forcing mechanisms (e.g. Trabucho-Alexandre et al., 2011), 


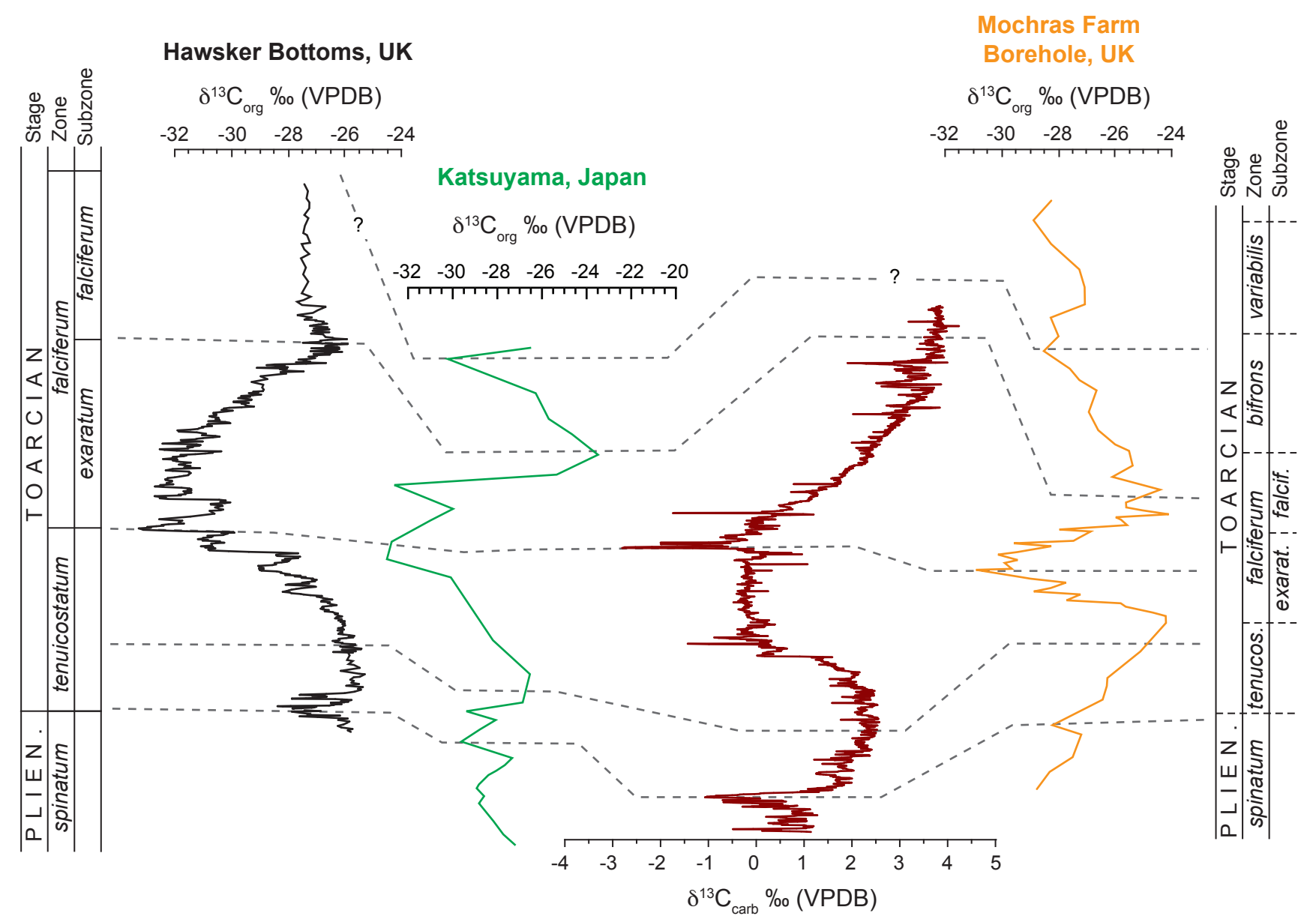

Peniche, Portugal

Fig. 6. Comparison of $\delta^{13} \mathrm{C}$ profiles for the Plienbachian-Toarcian time interval. Bulk-sediment data are compiled from Whitby (dataset is from both Port Mulgrave and Hawsker Bottoms) (Kemp et al., 2005; Littler et al., 2009), Katsuyama (this study), Peniche (Hesselbo et al., 2007) and Mochras Farm Borehole (Jenkyns et al., 2001). The $\delta^{13} \mathrm{C}$ profiles have been correlated using the negative excursion at the Pliensbachian/Toarcian boundary, positive values in the lower Toarcian, the negative values in the T-OAE, the subsequent positive excursion after the T-OAE, and finally the negative trend in the bifrons ammonite Zone between Mochras Farm Borehole and Katsuyama. Note that Peniche is the only carbonate carbon isotope record. This chemostratigraphic correlation of Toarcian successions suggests that the biostratigraphic scheme using Carter et al. (2010) is more relevant when not considering the presence of $H$. exiguum at ca. $100 \mathrm{~cm}$ (sensu Hori, 2011) and the lack of other key species indicative of the middle Toarcian.

in determining whether and when sediments at a particular location become enriched in organic matter.

Using the timescale adopted by Hori et al. (1993), the duration of the negative excursion across the Pliensbachian/Toarcian can be calculated at ca. $290 \mathrm{kyr}$, with the T-OAE covering a period of ca. $535 \mathrm{kyr}$. The latter value is somewhat similar to the recent estimate by Suan et al. (2008), who assigned a value of $600 \mathrm{kyr}$ for the duration of the TOAE negative excursion in the Lusitanian Basin. Suan et al. (2008) further suggested that the entire excursion (negative and positive excursion) lasted $900 \mathrm{kyr}$. If the end of the T-OAE excursion at Katsuyama is taken to occur between ca. $300-325 \mathrm{~cm}$ (Fig. 5), then a duration of ca. $1 \mathrm{Myr}$ is estimated.

\subsection{The Katsuyama T-OAE record: global carbon cycle signals and local oceanographic processes}

Hitherto, an open ocean succession deposited during the TOAE had never been studied for its carbon isotope record. The new chemostratigraphic record of the T-OAE presented in this study represents the first open ocean expression of the event. The correlation and comparison of the negative CIE at different localities shows that the geochemical signature of this OAE is similar between epi- and pericontinental, and open ocean localities (Fig. 6). Moreover, because the Katsuyama succession is truly pelagic and, at the time of deposition, away from land influence, the negative excursion is shown to indeed represent a primary global carbon signal. 

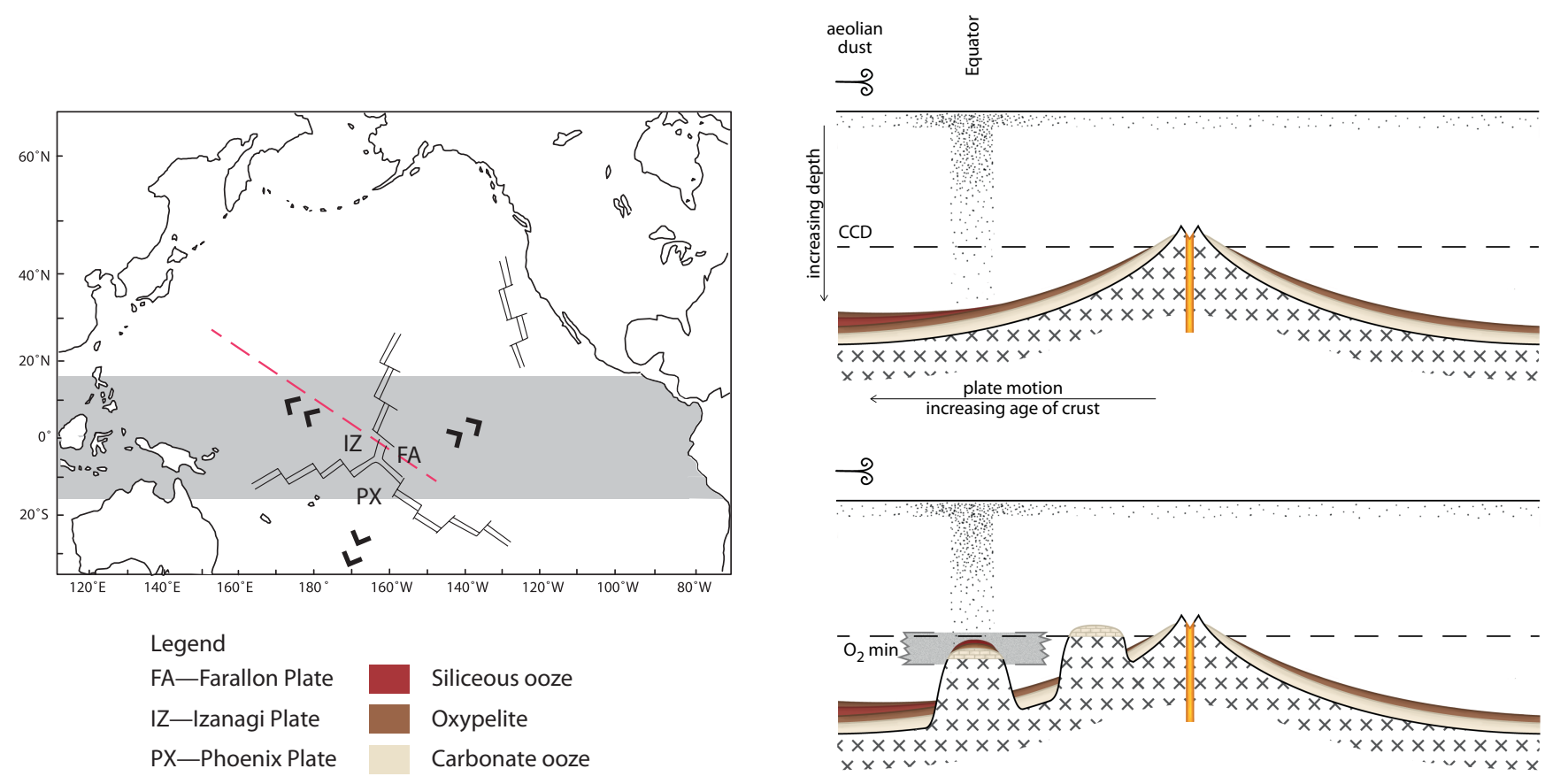

Fig. 7. (A) Present-day map of the Pacific region with Early Jurassic plate tectonic elements. The red dashed line shows the position of the cross-sections shown in panels B and C. Movement of tectonic plates indicated by arrows. The equatorial divergence zone is shown in grey. Base map modified from Robinson et al. (2004) and plate tectonic elements from Müller et al. (2008). (B) Schematic cross-section across the Early Jurassic Panthalassa showing the abyssal seafloor hypothesis for the formation of organic matter-rich chert. Izanagi Plate on the left. CCD stands for calcite compensation depth. The dotted pattern represents particulate matter. (C) Schematic cross-section across the Early Jurassic Panthalassa showing the mesopelagic/upper bathyal seamount hypothesis for the formation of organic matter-rich chert. The seamount is transported by seafloor spreading from right to left in the figure, i.e. towards the northwest in panel A.

The T-OAE is therefore defined (and the sediments deposited during the T-OAE associated with) by a negative excursion in the carbon isotope record that is recorded globally regardless of facies (Fig. 1). In the open ocean Katsuyama succession, the T-OAE interval is characterized by dysoxic, organic matter-rich biosiliceous facies, with periodic anoxia and euxinia intervening (Wignall et al., 2010).

The presence of abundant radiolarian tests, which are the precursory sediments for chert, in ooze is mainly limited to zones of high primary productivity. Moreover, higher productivity beyond a critical threshold results in higher proportions of biosiliceous surface production reaching the seafloor (Dewever et al., 1994). After death, the mineral skeletons are exposed to seawater, and dissolution is more pronounced in surface seawater. Indeed, contrary to general intuition, biogenic silica dissolution in the water column is greatest within the uppermost $500 \mathrm{~m}$ due to elevated temperature (e.g. Seibold and Berger, 1996). Due to these productivity and preservation requirements this would indicate that the sedimentary rocks at Katsuyama were probably deposited within the equatorial divergence zone at water depths in excess of $500 \mathrm{~m}$ (Fig. 7a).

In the Katsuyama succession, TOC contents range between $0.01-2.75 \%$. Two marked increases in TOC occur at ca. $45-100 \mathrm{~cm}$ and ca. $180-210 \mathrm{~cm}$, where the colour of the cherts changes from grey to black (Fig. 5). The presence of organic matter-rich sediments in the Katsuyama section can be explained by two alternative hypotheses, which mainly differ from each other in terms of depositional water depth. The open ocean Katsuyama cherts may be interpreted as having been deposited on the abyssal seafloor of the Izanagi Plate (Fig. 7b), or as having been deposited on the mesopelagic to upper bathyal seafloor of a volcanic seamount (Fig. 7c). In either case, the seafloor, which was originally created in the Southern Hemisphere (Fujii et al., 1993; Ando et al., 2001), migrated north-westwards across the equator (Fujii et al., 1993; Ando et al., 2001) to its current position by seafloor spreading (cf. Wilson et al., 1998). This is consistent with the idea that the seafloor was covered by pelagic sediments during its journey and, within the equatorial divergence zone, biosiliceous black shales were deposited as part of the pelagic sequence.

The longer export paths associated with the abyssal seafloor hypothesis make it unlikely that significant organic matter would reach the seafloor in order to be preserved (Fig. 7b). Anoxia in the open ocean is unlikely due to the large mass of subthermocline water (Wignall and Newton, 2001). Overturning circulation, largely driven by extremes 
of surface temperature and salinity, and stirring by wind and tides (e.g. Ledwell et al., 2000), promotes an effective ventilation of the water column; in combination with the longer settling times of particulate material from the euphotic zone to the seafloor, preservation of organic matter is very low. The seamount hypothesis is the most probable explanation since it accounts for the presence of organic matterrich sedimentary rocks in the studied succession (Fig. 7c). The seafloor of a seamount would have been closer to the euphotic zone and would have perhaps protruded the upper bathyal oxygen minimum layer, which is formed in layers of minimal advection of oxygen. As a result, export paths for organic matter would have been reduced, and the preservation of organic matter in the sediment favoured. No volcanics can be directly assigned to the chert succession as comprising the basement of the inferred seamount hypothesis. However, the volcanics may not have accreted.

The presence of black shales in open ocean settings needs not necessarily to represent a spread of anoxia in the oceans, but rather the passage of an ideal substrate for the preservation of organic matter through a zone in the ocean characterized by enhanced primary productivity in surface waters. The model in the seamount hypothesis helps to reconcile the presence of black shales in open ocean settings with evidence for upwelling in the open marine environment, for enhanced ocean overturning and with high $\mathrm{C} / \mathrm{S}$ ratios in pelagic settings during such events (Kajiwara et al., 1994; Suzuki et al., 1998; Trabucho-Alexandre et al., 2010), which cannot be easily explained by ocean anoxia and stable stratification.

The studied black shales are organic matter-rich radiolarian cherts and, therefore, attest to conditions of high productivity in the euphotic zone and of low oxygen at the seafloor. Whereas low oxygen conditions are a characteristic feature of the global oxygen minimum layer in the ocean, high productivity within the equatorial divergence zone would have resulted in a higher export of organic matter towards the seafloor. Due to the palaeogeographic setting of the Katsuyama section in the Early Jurassic, the T-OAE not only records the excursion in the carbon isotope record that is characteristic of this time interval from sections worldwide (Fig. 1) irrespective of setting (but cf. van de Schootbrugge et al., 2005), but it is also characterized by organic matter-rich open ocean lithologies. If this interpretation is correct, the enrichment in organic matter is largely accidental, i.e. if the Katsuyama section were not located within the equatorial divergence zone during the T-OAE, the lithological expression of this event (organic matter-rich cherts) would have been absent. The presence of the carbon isotope excursion in these open ocean sedimentary rocks, however, proves univocally that the T-OAE represents a perturbation in the global carbon cycle.

\subsection{Global forcing mechanisms behind the T-OAE CIE}

The seemingly localized nature of the lower Toarcian negative $\delta^{13} \mathrm{C}$ excursion, apparently confined to epicontinental successions of the Neotethyan realm (Europe), prompted a number of workers to question whether a global mechanism is capable of explaining the lower Toarcian excursion (e.g. Wignall et al., 2006; McArthur et al., 2008). Moreover, the lack of a negative $\delta^{13} \mathrm{C}$ excursion in the belemnite calcite record has been used by some authors to support the claim that isotopically light carbon did not dominate the oceanatmosphere system during the T-OAE (van de Schootbrugge et al., 2005; Wignall et al., 2006). An alternative hypothesis for the event has been offered which invokes local overturn of ${ }^{12} \mathrm{C}$-enriched dissolved $\mathrm{CO}_{2}$ from deeper waters to the surface, where photoautotrophic uptake of this carbon would consequently lead to a regional negative $\delta^{13} \mathrm{C}$ excursion (Küspert, 1982; Röhl et al., 2001; van de Schootbrugge et al., 2005; Wignall et al., 2006). This view is countered by evidence for a coeval negative CIE in terrestrial plant material (Hesselbo et al., 2000, 2007) and by the record presented in this study, outside of the Neotethyan realm (Europe) and in the open ocean. The overturn hypothesis was also questioned by van Breugel et al. (2006) who analysed isorenieratene abundances and $\delta^{13} \mathrm{C}$ across the record of the event in the Paris Basin (France) and concluded that respired $\mathrm{CO}_{2}$ could not have contributed significantly to the negative CIE. Indeed, in light of the data presented here, and those of the recent Al-Suwaidi et al. (2010) and Caruthers et al. (2011) studies from Argentina and Western Canada, respectively, the overturn scenario is improbable to have occurred synchronously at all these sites.

The emplacement of the Karoo-Ferrar large igneous province in the latest Pliensbachian is likely to be of significance in the development of the negative $\delta^{13} \mathrm{C}$ excursion that defines the T-OAE. Long-term injection of volcanic greenhouse gases (primarily $\mathrm{CO}_{2}$ ) into the atmosphere associated with the emplacement of large igneous provinces is thought to have led to an increase in global mean temperatures (Pálfy and Smith, 2000). Although the Toarcian palaeotemperature record in the Neotethys may have been influenced by a reduction in salinity (freshwater input) and/or latitudinal water flow through the NW European corridor (Bjerrum et al., 2001), belemnite-derived $\mathrm{Mg} / \mathrm{Ca}$ and $\delta^{18} \mathrm{O}$ palaeotemperature calculations show an increase in seawater temperature through the latest Pliensbachian and early Toarcian (McArthur et al., 2000; Rosales et al., 2004). In turn, rising temperatures would have led to the dissociation of methane clathrates, increasing atmospheric and seawater temperatures, an enhanced hydrological cycle, and a biotic crisis: akin to the PETM (e.g. Cohen et al., 2007; Dickens, 2011 and references therein). 


\section{Conclusions}

The palaeogeography of black shale depositional environments during OAEs is a matter of discussion. All previously known examples of Toarcian black shales were deposited on epi- and pericontinental shelves in environments proximal to Pangaea. In this study, a truly pelagic, open ocean setting is documented. The Katsuyama black shales are here interpreted as having been deposited on the seafloor of a volcanic seamount due to its passage under the highly productive waters of the equatorial divergence zone of Panthalassa. The shorter export path for organic matter resulting from the presence of a submarine topographical high, in association with the expansion of the oxygen minimum layer due to high oxygen demand, favoured the preservation of organic matter and led to biosiliceous black shale formation. Thus, it appears that the palaeogeographic distribution of black shales during the T-OAE is similar to that of other Mesozoic OAEs and to that of PETM black shales (cf. Thomas, 2007), i.e. mostly restricted to shelf environments.

The perturbation in the carbon cycle during the T-OAE was a global phenomenon that affected all active carbon reservoirs, which is recorded by a negative CIE in terrestrial and marine sediments (both shallow and deep ocean settings). Therefore, the forcing mechanism(s) behind the T-OAE must have been capable of driving global environmental change. These mechanisms may have included: the eruption of the Karoo-Ferrar continental flood basalts and/or the massive dissociation of continental margin clathrates with a resulting increased hydrological cycle and a transient greenhouse climate with increased $\mathrm{CO}_{2}$ concentrations and palaeotemperatures. Apart from the T-OAE CIE, the Pliensbachian/Toarcian CIE is also recorded in the Katsuyama cherts also suggesting it is global. These CIEs are important for understanding the Early Jurassic carbon cycle, as well as a tool for stratigraphic correlation between diverse palaeogeographic realms.

Acknowledgements. The authors thank Michael Arthur, Hugh Jenkyns and Guillaume Suan for insightful and helpful comments on this dataset. This project was funded by a JSPS Research Fellowship, a NSERC Discovery Grant (\# 288321) and NERC Standard Grant (NE/H020756/1) to DRG. JTA is funded by the NERC Standard Grant (NE/H020756/1) to DRG. DBK acknowledges receipt of a Girton College, Cambridge, Junior Research Fellowship. Joanne Peterkin provided assistance with the stable isotope measurements, and the facility was financially supported by TOTAL UK. The authors thank the editors, Poppe de Boer and Stuart Robinson, and the reviewers, Gerald Dickens, Jószef Pálfy and Bas van de Schootbrugge, for their comments and suggestions that greatly improved the manuscript.

Special Issue: "Phanerozoic black shales and oceanic anoxic events: geochemistry, sedimentology and stratigraphy"

Edited by: J. Trabucho-Alexandre, P. L. de Boer, and D. R. Gröcke

\section{References}

Al-Suwaidi, A. H., Angelozzi, G. N., Baudin, F., Damborenea, S. E., Hesselbo, S. P., Jenkyns, H. C., Manceñido, M. O., and Riccardi, A. C.: First record of the Early Toarcian Oceanic Anoxic Event from the Southern Hemisphere, Neuquén Basin, Argentina, J. Geol. Soc. London, 167, 1-4, 2010.

Ando, A., Kodama, K., and Kojima, S.: Low-latitude and Southern Hemisphere origin of Anisian (Triassic) bedded chert in the Inuyama area, Mino terrane, central Japan, J. Geophys. Res., 106, 1973-1986, 2001.

Beerling, D. J., Lomas, M. R., and Gröcke, D. R.: On the nature of methane gas dissociation during the Toarcian and Aptian oceanic anoxic events, Am. J. Sci., 302, 28-49, 2002.

Bjerrum, C. J., Surlyk, F., Callomon, J. H., and Slingerland, R. L.: Numerical paleoceanographic study of the Early Jurassic transcontinental Lausarian seaway, Paleoceanography, 16, 390404, 2001.

Carter, E. S., Gorièan, Guex, J., O’Dogherty, L., de Wever, P., Dumitrica, P., Hori, R. S., Matsuoka, A., and Whalen, P. A.: Global radiolarian zonation for the Pliensbachian, Toarcian and Aalenian, Palaeogeogr. Palaeocl., 297, 401-419, 2010.

Caruthers, A. H., Gröcke, D. R., and Smith, P. L.: The significance of an Early Jurassic (Toarcian) carbon-isotope excursion in Haida Gwaii (Queen Charlotte Islands), British Columbia, Canada, Earth Planet. Sc. Lett., 307, 19-26, 2011.

Cohen, A. S., Coe, A. L., Harding, S. M., and Schwark, L.: Osmium isotope evidence for the regulation of atmospheric $\mathrm{CO}_{2}$ by continental weathering, Geology, 32, 157-160, 2004.

Cohen, A., Coe, A., and Kemp, D.: The Late Palaeocene Early Eocene and Toarcian (Early Jurassic) carbon isotope excursions: a comparison of their time scales, associated environmental changes, causes and consequences, J. Geol. Soc. Lond., 164, 1093-1108, 2007.

Dewever, P, Azema, J., and Fourcade, E.: Radiolarians and radiolarites-primary production, diagenesis and palaeogeography, B. Cent. Rech. Expl., 18, 315-379, 1994.

Dickens, G. R.: Down the Rabbit Hole: toward appropriate discussion of methane release from gas hydrate systems during the Paleocene-Eocene thermal maximum and other past hyperthermal events, Clim. Past, 7, 831-846, doi:10.5194/cp-7-831-2011, 2011.

Fujii, J., Hattori, I., and Nakajima, T.: A study of radiolarian biostratigraphy and magnetostratigraphy of early Mesozoic red bedded chert, central Japan: News Osaka Micropaleontology, 9, 7189, 1993. (in Japanese with English translation).

Gröcke, D. R., Rimmer, S. M., Yoksoulian, L. E., Cairncross, B., Tsikos, H., and van Hunen, J.: No evidence for thermogenic methane release in coal from the Karoo-Ferrar large igneous province, Earth Planet. Sc. Lett., 277, 204-212, 2009.

Hallam, A.: Sedimentology and palaeogeographic significance of certain red limestones and associated beds in the Lias of the Alpine region, Scot. J. Geol., 3, 195-220, 1967.

Hesselbo, S. P., Gröcke, D. R., Jenkyns, H. C., Bjerrum, C., Farrimond, P., Morgans Bell, H., and Green, O.: Massive dissociation of gas hydrate during a Jurassic oceanic anoxic event, Nature, 406, 392-395, 2000.

Hesselbo, S. P., Jenkyns, H. C., Duarte, L. V., and Oliveira, L. C. V.: Carbon-isotope record of the Early Jurassic (Toarcian) Oceanic Anoxic Event from fossil wood and marine carbonate 
(Lusitanian Basin, Portugal), Earth Planet. Sc. Lett., 253, 455470, 2007.

Hori, R. S.: Lower Jurassic radiolarian zones of SW Japan, Transactions, P. Palaeontol. Soc. Japan, 151, 543-563, 1990.

Hori, R. S.: Toarcian Oceanic Event in deep-sea sediments, B. Geol. Surv. Japan, 44, 555-570, 1993.

Hori, R. S.: The Toarcian radiolarian event in bedded cherts from southwest Japan, Mar. Micropaleontol., 30, 159-169, 1997.

Hori, R. S., Cho, C.-F., and Umeda, H.: Origin of cyclicity in Triassic-Jurassic radiolarian bedded cherts of the Mino accretionary complex from Japan, Isl. Arc, 3, 170-180, 1993.

Iijima, A., Inagaki, H., and Kakuwa, Y.: Nature and origin of the Paleogene cherts in the Setogawa Terrain, Shizuoka, Central Japan, J. Fac. Sci. U. Tokyo, 20, 1-30, 1979.

Jenkyns, H. C.: The Early Toarcian and Cenomanian-Turonian anoxic events in Europe: comparisons and contrasts, Geol. Rundsch., 74, 505-518, 1985.

Jenkyns, H. C. and Clayton, C. J.: Black shales and carbon isotopes in pelagic sediments from the Tethyan Lower Jurassic, Sedimentology, 33, 87-106, 1986.

Jenkyns, H. C. and Wilson, P. A.: Stratigraphy, paleoceanography, and evolution of Cretaceous Pacific guyots; relics from a greenhouse Earth, Am. J. Sci., 299, 341-392, 1999.

Jenkyns, H. C., Gröcke, D. R., and Hesselbo, S. P.: Nitrogenisotope evidence for watermass denitrification during the Early Toarcian (Jurassic) Oceanic Anoxic Event, Paleoceanography, 16, 593-603, 2001.

Jenkyns, H. C., Jones, C. E., Gröcke, D. R., Hesselbo, S. P., and Parkinson, D. N.: Chemostratigraphy of the Jurassic System: applications, limitations and implications for palaeoceanography, J. Geol. Soc. Lond., 159, 351-378, 2002.

Kajiwara, Y., Yamakita, S., Ishida, K., Ishiga, H., and Imai, A.: Development of a largely anoxic stratified ocean and its temporary massive mixing at the Permian/Triassic boundary supported by the sulphur isotopic record, Palaeogeogr. Palaeocl., 111, 367379, 1994.

Kemp, D. B., Coe, A. L., Cohen, A. S., and Schwark, L.: Astronomical pacing of methane release in the Early Jurassic period, Nature, 437, 396-399, 2005.

Kimura, K. and Hori, R.: Offscraping accretion of Jurassic chertclastic complexes in the Mino-Tamba Belt, central Japan, J. Struct. Geol., 15, 145-161, 1993.

Küspert, W.: Environmental changes during oil shale deposition as deduced from stable isotope ratios, in: Cyclic and Event Stratification, edited by: Einsele, G. and Seilacher, A., Springer, Berlin, Germany, 482-501, 1982.

Ledwell, J. R., Montgomery, E. T., Polzin, K. L., Laurent, L. C. S., Schmitt, R. W., and Toole, J. M.: Evidence for enhanced mixing over rough topography in the abyssal ocean, Nature, 403, 179$182,2000$.

Little, C. T. S. and Benton, M. J.: Early Jurassic mass extinction: a global long-term event, Geology, 23, 495-498, 1995.

Littler, K., Hesselbo, S. P., and Jenkyns, H. C.: A carbon-isotope perturbation at the Pliensbachian-Toarcian boundary: evidence from the Lias Group, NE England, Geol. Mag., 147, 181-192, 2009.

Matsuda, T. and Isozaki, Y.: Well-documented travel history of Mesozoic pelagic chert in Japan: From remote ocean to subduction zone, Tectonics, 10, 475-499, 1991.
Matsuoka, A.: Jurassic and Lower Cretaceous radiolarian zonation in Japan and in the western Pacific, Island Arc, 4, 140-153, 1995.

Matsuoka, A.: Toarcian (Early Jurassic) radiolarian fauna from the Nanjo Massif in the Mino Terrane, central Japan, News Osaka Micropaleontology, 13, 69-87, 2004.

Mattioli, E., Pittet, B., Bucefalo Palliani, R., Röhl, H.-J., SchmidRöhl, A., and Morettini, E.: Phytoplankton evidence for timing and correlation of palaeoceanographical changes during the early Toarcian oceanic anoxic event (Early Jurassic), J. Geol. Soc. Lond., 161, 685-693, 2004.

McArthur, J. M., Donovan, D. T., Thirwall, M. F., Fouke, B. W., and Mattey, D.: Strontium isotopic profile of the early Toarcian (Jurassic) oceanic anoxic event, the duration of ammonite biozones, and belemnite palaeotemperatures, Earth Planet. Sc. Lett., 179, 269-285, 2000.

McArthur, J. M., Algeo, T., van de Schootbrugge, B., Li, Q., and Howarth, R.: Basinal restriction, black shales, Re-Os dating, and the Early Toarcian (Jurassic) oceanic anoxic event, Paleoceanography, 23, PA4217, doi:10.1029/2008PA001607, 2008.

McElwain, J. C., Wade-Murphy, J., and Hesselbo, S. P.: Changes in carbon dioxide during an oceanic anoxic event linked to intrusion into Gondwana coals, Nature, 435, 479-482, 2005.

Müller, R. D., Sdrolias, M., Gaina, C., and Roest, W. R.: Age, spreading rates, and spreading asymmetry of the world's ocean crust, Geochem. Geophy. Geosy., 9, Q04006, doi:10.1029/2007GC001743, 2008.

Otsuka, T. and Watanabe, K.: Illite crystallinity and low-grade metamorphism of Pelitic rocks in the Mino Terrane, central Japan, Mem. Geol. Soc. Japan, 38, 135-145, 1992. (in Japanese with English abstract).

Pálfy, J. and Smith, P. L.: Synchrony between Early Jurassic extinction, oceanic anoxic event, and the Karoo-Ferrar flood basalt volcanism, Geology, 28, 747-750, 2000.

Robinson, S. A., Williams, T., and Bown, P. R.: Fluctuations in biosiliceous production and the generation of Early Cretaceous oceanic anoxic events in the Pacific Ocean (ODP Leg 198, Shatsky Rise), Paleoceanography, 19, PA4024, doi:10.1029/2004PA001010, 2004.

Röhl, H. J., Schmid-Röhl, A., Oschmann, W., Frimmel, A., and Schwark, L.: The Posidonia Shale (Lower Toarcian) of SWGermany: an oxygen-depleted ecosystem controlled by sea level and palaeoclimate, Palaeogeogr. Palaeocl., 165, 27-52, 2001.

Rosales, I., Quesada, S., and Robles, S.: Paleotemperature variations of Early Jurassic seawater recorded in geochemical trends of belemnites from the Basque-Cantabrian basin, northern Spain, Palaeogeogr. Palaeocl., 203, 253-275, 2004.

Schouten, S., van Kaam-Peters, H. M. E., Rijpstra, W. I. C., Schoell, M., and Sinninghe Damsté, J. S.: Effects of an oceanic anoxic event on the stable carbon isotopic composition of early Toarcian carbon, Am. J. Sci., 300, 1-22, 2000.

Seibold, E. and Berger, W. H.: The sea floor: an introduction to marine geology, Springer-Verlag, Berlin, 1996.

Shibuya, H. and Sasajima, S.: Paleomagnetism of red cherts: A case study in the Inuyama area central Japan, J. Geophys. Res., 91, 14105-14116, 1986.

Suan, G., Mattiolli, E., Pettit, B., Mailliot, S., and Lécuyer, C.: Evidence for major environmental perturbation prior to and during the Toarcian (Early Jurassic) oceanic anoxic event from the Lusitanian Basin, Portugal, Paleoceanography, 23, PA1202, 
doi:10.1029/2007PA001459, 2008.

Suzuki, N., Ishida, K., Shinomiya, Y., and Ishiga, H.: High productivity in the earliest Triassic ocean: black shales, Southwest Japan, Palaeogeogr. Palaeocl., 141, 53-65, 1998.

Svensen, H., Planke, S., Chevallier, L., Malthe-Sorenssen, A., Corfu, F., and Jamtveit, B.: Hydrothermal venting of greenhouse gases triggering Early Jurassic global warming, Earth Planet. Sc. Lett., 256, 554-566, 2007.

Takeuchi, M.: Morphologic study of multicyrtid Nassellaria (Radiolaria) from the Lower Jurassic bedded cherts in the Inuyama Area, Mino Terrane, Central Japan, News Osaka Micropaleontology, 12, 181-189, 2001.

Thomas, E.: Cenozoic mass extinctions in the deep sea: what perturbs the largest habitat on Earth?, in: Large Ecosystem Perturbations: Causes and Consequences, edited by: Monechi, S., Coccioni, R., and Rampino, M. R., Geol. S. Am. S., 424, 1-23, 2007.

Trabucho-Alexandre, J., Tuenter, E., Henstra, G. A., van der Zwan, K. J., van de Wal, R. S. W., Dijkstra, H. A., and de Boer, P. L.: The mid-Cretaceous North Atlantic nutrient trap: black shales and OAEs, Paleoceanography, 25, PA4201, doi:10.1029/2010PA001925, 2010.

Trabucho-Alexandre, J., van Gilst, R. I., Rodríguez-López, J. P., and de Boer, P. L.: The sedimentary expression of oceanic anoxic event $1 \mathrm{~b}$ in the North Atlantic, Sedimentology, 58, 1217-1246, 2011.

Tremolada, F., van de Schootbrugge, B., and Erba, E.: Early Jurassic schizosphaerellid crisis in Cantabria, Spain: implications for calcification rates and phytoplankton evolution across the Toarcian oceanic anoxic event, Paleoceanography, 20, PA2011, doi:10.1029/2004PA001120, 2005.

Tsikos, H., Jenkyns, H. C., Walsworth-Bell, B., Petrizzo, M. R., Forster, A., Kolonic, S., Erba, E., Premoli Silva, I., Baas, M., Wagner, T., and Sinninghe Damsté, J. S.: Carbon-isotope stratigraphy recorded by the Cenomanian-Turonian Oceanic Anoxic Event: correlation and implications based on three key localities, J. Geol. Soc. Lond., 161, 711-719, 2004. van Breugel, Y., Baas, M., Schouten, S., Mattioli, E., and Sinninghe Damsté, J. S.: Isorenieratane record in black shales from the Paris Basin, France: Constraints on recycling of respired $\mathrm{CO}_{2}$ as a mechanism for negative carbon isotope shifts during the Toarcian oceanic anoxic event, Paleoceanography, 21, PA4220, doi:10.1029/2006PA001305, 2006.

van de Schootbrugge, B., McArthur, J. M., Bailey, T. R., Rosenthal, Y., Wright, J. D., and Miller, K. G.: Toarcian oceanic anoxic event: An assessment of global causes using belemnite C isotope records, Paleoceanography, 20, PA3008, doi:10.1029/2004PA001102, 2005.

Waltham, D. and Gröcke, D. R.: Non-uniqueness and interpretation of the seawater ${ }^{87} \mathrm{Sr} /{ }^{86} \mathrm{Sr}$ curve, Geochim. Cosmochim. Ac., 70 384-394, 2006.

Wignall, P. B. and Newton, R.: Black shales on the basin margin: a model based on examples from the Upper Jurassic of the Boulonnais, northern France, Sed. Geol., 144, 335-356, 2001.

Wignall, P. B., Newton, R. J., and Little, C. T. S.: The timing of paleoenvironmental change and cause-and-effect relationships during the Early Jurassic mass extinction in Europe, Am. J. Sci., 305, 1014-1032, 2005.

Wignall, P. B., McArthur, J. M., Little, C. T. S., and Hallam, A.: Methane release in the Early Jurassic period, Nature, 441, E5, doi:10.1038/nature04905, 2006.

Wignall, P. B., Bond, D., Kuwahara, K., Kakuwa, Y., Newton, R. J., and Poulton, S. W.: An 80 million year oceanic redox history from Permian to Jurassic pelagic sediments of the MinoTamba terrane, SW Japan, and the origin of four mass extinctions, Global Planet. Change, 71, 109-123, 2010.

Wilson, P. A., Jenkyns, H. C., Elderfield, H., and Larson, R. L.: The paradox of drowned carbonate platforms and the origin of Cretaceous Pacific guyots, Nature, 392, 889-894, 1998.

Yao, A., Matsuoka, A., and Nakatani, T.: Triassic and Jurassic radiolarian assemblages in Southwest Japan, News Osaka Micropaleontology, 5, 27-43, 1982. 